\title{
GREEN TAXES, QUOTAS AND EQUALITY PRESERVING SOCIAL JUSTICE WHILST AVERTING CLIMATE CHANGE
}

\author{
Paula CASAl
}

The need for green fiscal reform is urgent in the face of climate change. Some oppose it, however, arguing that such reforms disproportionately burden poorer individuals whose emissions are far smaller than those of wealthier individuals. Defusing these criticisms, this paper argues that this is not an inevitable feature of green fiscal reform. We should adopt a more scientific attitude not only towards climate change but towards testing fiscal proposals to mitigate it, and avoid dividing, with rushed assumptions, responsible voters who care about both equality and climate change.

Keywords: climate change, carbon quotas and taxes, regressive taxes, inequality, green fiscal reform.

\section{THE INEQUALITY OBJECTION}

Averting climate change requires the prompt employment of a variety of measures, including fiscal measures. The latter are often criticised for their potential social impact. In fact, the most frequently voiced argument against climate taxes is that they are regressive and hurt most lower income groups who have contributed less to climate change (Wier, Birr-Pedersen, Klinge Jacobsen, \& Klok, 2005). Even former President of the Spanish government José Luis Rodríguez Zapatero, for example, responded to a proposal for green fiscal reform by the MP Joan Herrera thus:

\section{We must address the issue of green taxation but we must avoid making life more difficult for poorer individuals by causing prices to rise even more, and we must avoid following the countries outside Europe that employ subsidies and price regulations, which have proven a bad idea. ${ }^{1}$}

Climate taxes are believed to be regressive because poorer individuals (i) tend to consume a larger portion of their income than wealthier individuals who can save more; and (ii) tend to spend their income on items which will be subjected to green taxes such as food, water and energy bills and transport, rather than,

1 Televised debate on the State of the Nation, TV2, May 12, 2009. say, on services, art and design. Most people deem regressive taxes unfair. The risk of their increasing inequality beyond some parameters, moreover, raises further objections. For example, there is evidence regarding the deleterious effects of inequality on life expectancy, infant mortality, teenage births, homicide, drug use, length and quality of imprisonment, obesity, lack of community and trust, poor education and mental and physical illness (Wilkinson \& Pickett, 2009). There is also evidence that equal societies are more sustainable, recycle more, and manage to provide public goods like education or healthcare at a lower environmental cost (Wilkinson \& Pickett, 2009, pp. 217-235). Inequality, moreover, is higher than it has ever been and continues to grow at alarming rates (Piketty, 2014). Finally, the very same individuals or groups who would support taking action against climate change are also likely to oppose measures that increase inequality. This problem is sometimes accentuated by a valueladen aversion to market instruments in influential progressive thinkers (e.g. Goodin, 1994; Sandel, 2012). It is important, however, that we adopt a scientific attitude, not only to climate change, but also to the fiscal measures designed to mitigate it, and avoid the wholesale rejection of instruments that may or may not possess certain distributive disadvantages depending on specific aspects of their implementation. 


\section{REGULATIONS AND MARKET INSTRUMENTS}

It is common to distinguish between «command and control» (or regulations) and «market instruments» (or taxation) and to associate the first with stateintervention; the latter with a market economy, as Zapatero suggests. However, in practice, governments of all kinds chose their instruments on pragmatic grounds. The US, for example, has been relying heavily on energy efficiency regulations because of how difficult it is to introduce new taxes in that country.

Regulations are simply strategies that place limits on each agent's consumption, through bans or rations, while market instruments are strategies that involve price modifications through taxes and permits (Pearce, 1995). Regulations may involve replacing a whole system for another, such as cars by public transport or coal by gas, whilst market instruments create incentives to develop and adopt superior methods, for example, of transport or heating. Prohibitions and fines send a clearer message of condemnation to society, whilst taxes and permits suggest that pollution is a normal and acceptable part of any productive enterprise. The best system, however, may require combining both. For example, it is inefficient to provide public transport if buses run empty while people drive past them in their cars. Taxes on cars or road use can make the collective solution sufficiently popular; but if there is no collective solution, people will still drive their highly-taxed cars. Both approaches, thus, can complement rather than exclude each other.

Economic instruments have several advantages. First, sometimes it is inexpensive for a firm to reduce pollution to a certain point, but very costly to reduce it further. Uniform limits risk inefficiency because they lack flexibility. Second, limits offer no incentives to reduce polluting below the permitted level. Third, sometimes market instruments are actually fairer because they spread the costs more widely, whilst some regulations, like zoning restrictions, fall more heavily on some. Finally, as pollution taxes are administered via the existing tax framework, the risk of evasion is lower than when emissions are policed by irregular on-site inspections (Pearce, 1995, p. 208).

\section{UPSTREAM TRADABLE QUOTAS}

Where critical environmental thresholds are at stake, taxes can involve risks due to imperfect information about how agents will respond to initial tax rates. However, since companies often treat fines as taxes, fixed limits may not guarantee those limits are respected, unless the penalty is sufficiently high - and then sufficiently high taxes may be equally effective. «Cap-and-trade systems», or «quota auctions» ensure critical thresholds are not surpassed whilst incorporating market efficiency.

Having set a limit on aggregate pollution or consumption we may auction pollution or consumption permits of various types. For example, Netting (introduced in the United States in 1974) allows a firm to create new emissions if it offsets them by reductions elsewhere in the same plant; Offsets (1976) permit a firm to create new pollution sources if it offsets them in existing sources within the same firm or other local firms; Bubbles (1979) allows variation in the source of pollution within one or more firms, providing an overall limit is respected; and Banking (1979) works like Bubbles, but operates across time.

Like taxes, cap-and-trade schemes can be implemented

either «upstream» when applied to entire countries, or large producers and importers, or «midstream» when applied to all units exceeding some threshold, such as the twenty megawatts line in the European Emissions Trading Scheme. They can even apply «downstream» at individual level. The fact that a scheme is upstream or downstream can make an enormous difference, as a problem at one level may not exist at another. For example, unlike downstream trade-schemes, up and midstream schemes have been criticised for undermining an international ethos of shared responsibility, and for creating loopholes that enable rich countries to evade their obligations (Sandel, 2012). Some climate experts, including James Hansen, 


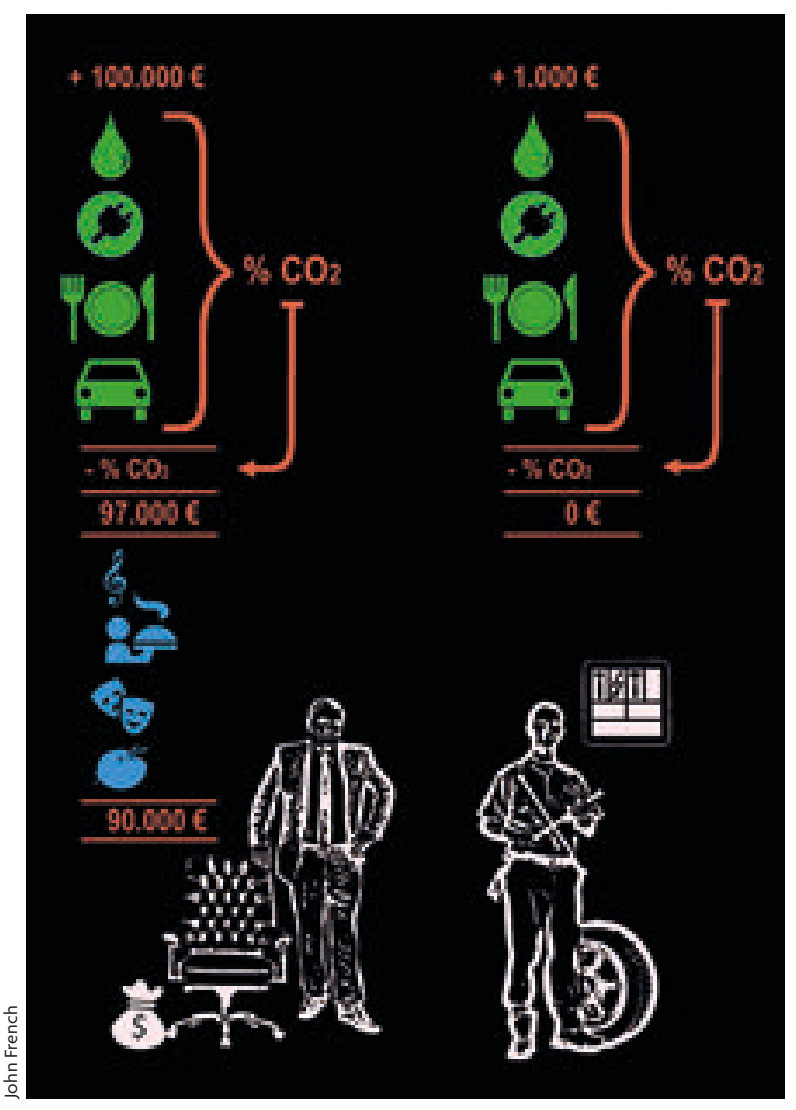

The lower the income of an individual (represented with the worker on the right), the more they will tend to spend all of it on green-taxed items, so their entire income (but only a small fraction of a higher income, represented with the whitecollar executive on the left) would be subject to the green tax. Therefore, the risk of regressivity exists, but it can be avoided. inequality or unfairness objection described earlier, and to which I now turn.

\section{TAXATION AND EQUALITY}

The most obvious response to the objection that green taxes are unfair because of their regressive character is that what matters is not the effect of each tax, but the net effect of the whole tax-and transfer system. If the introduction of a climate tax is accompanied by the reduction of a tax like VAT, there need be no increase in either taxes or regressivity. If, moreover, the green tax is made progressive in any of the ways described below, there could be a net reduction on what lower-income groups currently pay. Second, since the effects of a fiscal reform vary with factors external to it - such as how the poor travel or keep warm - such effects cannot be predicted without proper research, or experimental introductions of particular taxes in a certain period and area. Third, it is possible to point at many green taxes which are not regressive. Across the car-owning community, for example, motoring taxes tend to have a progressive effect, as the number of cars in a household, as well as the size and power of each one, tend to correlate with income. Even gasoline taxes are not as regressive as normally assumed (Poterba, 1991). A study of European taxes on transport fuel found the evidence of their regressivity weak (Sterner, 2012) and an Italian study found no regressivity (Tiezzi, 2005). Much depends on how regressivity is measured, on various aspects of the tax's implementation, and on how the revenue is employed. Moreover, it is not too difficult to design a carbon tax that imposes a higher rate on those who consume carbon above a threshold, and again at an even higher rate on those who consume above a second, higher threshold. Part of the force of the objection rests on the plausible assumption that there is a fairly systematic coincidence between those who consume more, and those who can consume more (the rich). This assumption simplifies the search for solutions, which include the following:

\section{Luxury taxes}

An obvious, non-regressive solution involves «luxury taxes» on items like second homes, tropical woods, international flights and holidays, fast cars, speed 
boats, jet skis, and sports utility vehicles which poor people are unlikely to purchase.

\section{Tax Rebates}

A second option involves taxing all items and either introducing partial or total exemptions for necessities or rebating a fixed amount to each taxpayer annually. Imagine, for example, a rebate equalling the tax rate multiplied by the minimum wage. Supposing the annual minimum wage was $\$ 10,000$, and the tax rate was $15 \%$, the rebate would be $\$ 1,500$. Thus, a minimum wage earner spending all his income will pay no expenditure taxes. Since modest rebates are hardly progressive among the wealthy, some authors combine them with progressive income taxes for highincome groups (McCaffery, 1992). Regarding children, perhaps half an adult rebate could be granted per child to a maximum of two per family. This system can be employed to tax all spending, to tax mainly or only environmental consumption, or to tax something even more specific, like carbon, by taxing fuels at source and distributing the revenue equally, as James Hansen has proposed (2009, pp. 209-222).

\section{Progressive expenditure taxes with environmental taxes}

An individual's expenditure, which is the result of subtracting a person's savings from her income, can easily be subjected to a progressive tax (Fellows, 1994; Frank \& Cook, 1995; Seidman, 1999). Since this will involve taxing all spending, environmental consumption would have to be subject to additional taxes, which could themselves be luxury taxes, taxes on carbon and other substances, or both.

\section{Environmental debit cards}

The environmental impact of an individual's consumption can be recorded much as we record individual savings. Individuals may be able to purchase goods without any additional charge, so long as they have not used up their allowance. If they do, incurring an «ecological debt», they will pay a surcharge, which will increase the more they spend.

The scheme might focus on the amount of carbon an individual uses and count only a few items like housing, flights, cars, boats, bikes, petrol and energy. Additional items can be added after the pilot phase,

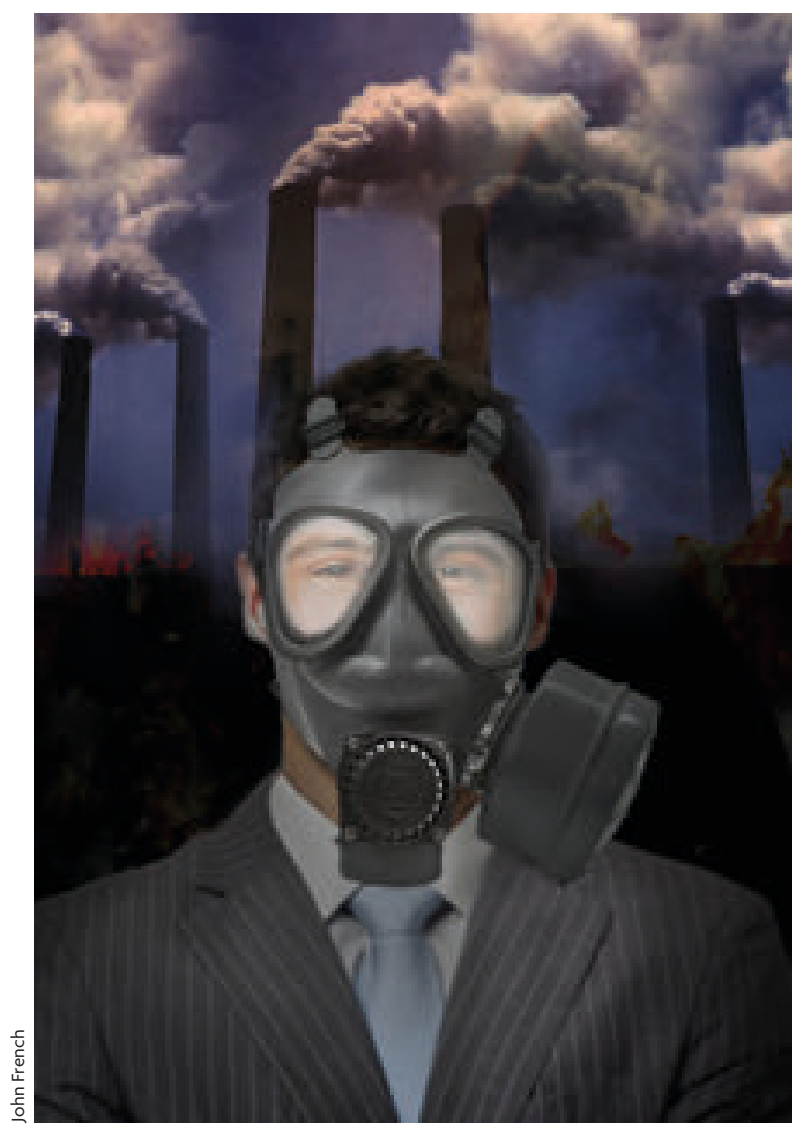

including non-carbon globalwarming agents. Depending on political feasibility, and how much, and how urgently, consumption of certain resources must be reduced, the relevant authorities would determine the amounts that individuals will be permitted to consume tax-free, and the rate to be imposed on those who exceed it.

A tax-free ration can be justified by appealing to sufficiency principles that grant special status to the satisfaction of our basic needs (Casal, 2007) and by noting that what is objectionable, and taxable, is not consumption as such but rather consumption exceeding some threshold. For example, the Dutch carbon and energy tax on households and small businesses applies only for use between 800-170,000 $\mathrm{m}^{3}$ of gas and $800-50,000 \mathrm{kWh}$ of electricity, in recognition of the impossibility of reducing consumption to zero.

Exemptions, however, do not eliminate regressivity and neither the individuals below the threshold 


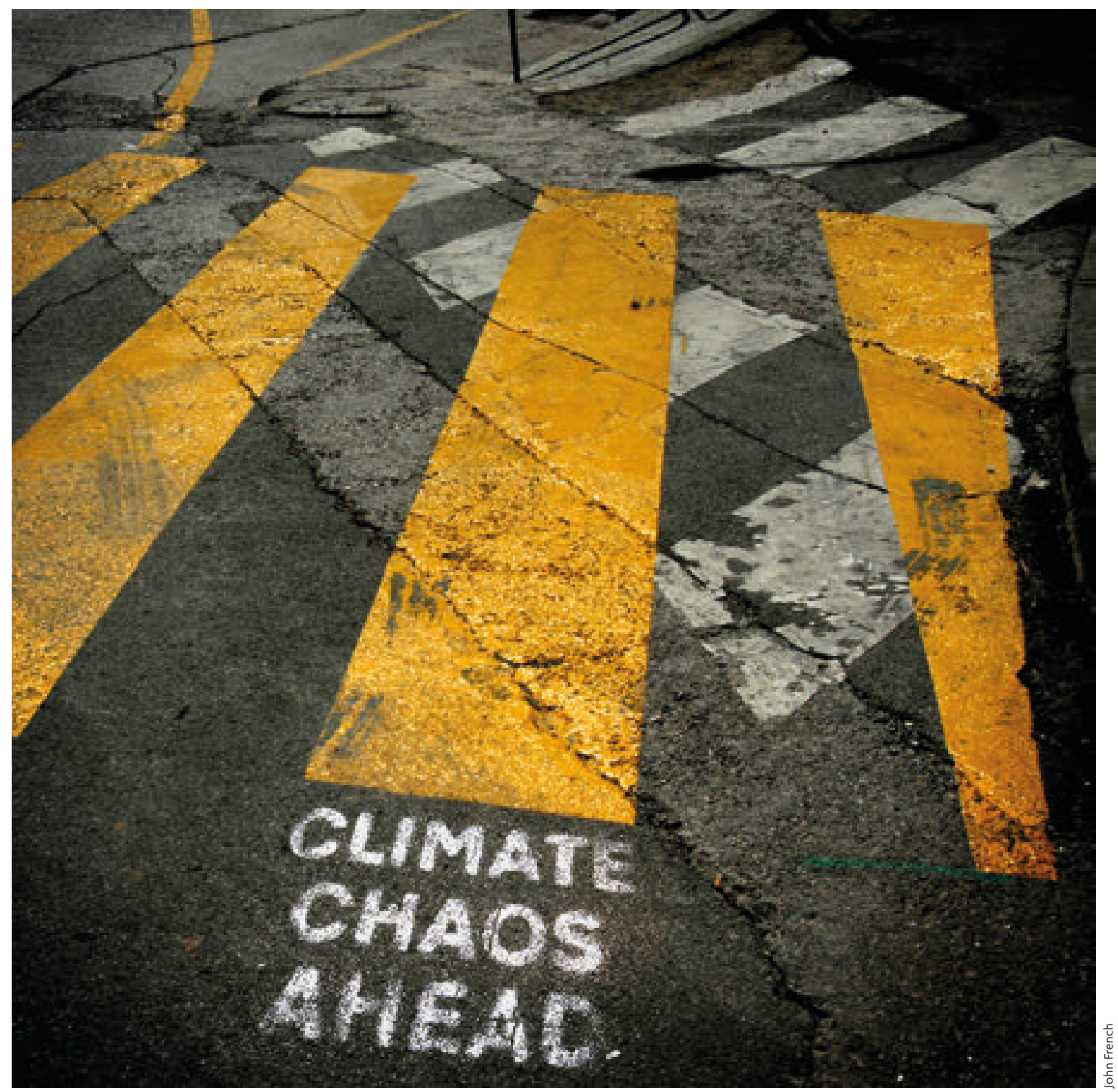

nor those far above it may be motivated to reduce consumption further. Both problems disappear, though, when tax rates rise as an individual's consumption above the relevant threshold also increases. Imagine that transactions are computer-monitored, and depending on the buyer's consumption history, a different rate is automatically applied. For example, one might be allowed to consume $n$ units of carbon at a zero tax rate, and then taxed at $10 \%$ for the next $n$ units, $20 \%$ for the subsequent $n$ units, and so on.

Payment cards with a magnetic strip indicating consumption histories could monitor environmental consumption. Electronic cards also allow the introduction of a mechanism to discourage short-
"A SYSTEM OF INDIVIDUAL TRADABLE QUOTAS MAY STILL HELP TO DIMINISH NOT ONLY POLLUTION BUT ALSO INEQUALITY, SINCE INDIVIDUALS WHO CONSUME LESS WILL HAVE MORE PERMITS TO SELL» 
sighted overspending (Galle, 2011). To secure compliance, appropriate discounts could be obtained only by presenting the card. If other taxes are not reduced to preserve tax neutrality, the additional revenue could finance environmental improvements or a basic income that frugal consumers could derive by selling their unused permits to the state. Black markets may develop, but if penalties are high, taking risks for small items would be irrational, and hiding large purchases like cars and houses is not easy. Most people do not disguise their income as someone else's to pay lower taxes and may be even more reluctant to declare their homes or vehicles as somebody else's. Besides steep fines, they may end up with invalid licenses or insurance claims or sales that fall through. In addition, there is another option.

\section{DOWNSTREAM TRADABLE QUOTAS}

All consumption permits could be exchanged in a permits market, not a black market but an authorised one. Consequently, all permits will have the same price and the initial progressivity will disappear. It would become a capand-trade system at individual level. At this level, concerns with mid and upstream schemes, like those regarding monopolies, international enforcement or complex bureaucracies, may not arise. In addition, the scheme may still help to diminish not only pollution but also inequality - since individuals who consume less will have more permits to sell. The scheme could support a basic income, unconditional upon willingness to work but sensitive to consumption habits. This method of financing basic income is less likely to generate resentment on the part of the industrious or to dampen incentives to work than one financed exclusively through income taxes. David Miliband, a politician who is ideologically close to Zapatero, proposed a scheme of personalised, tradable carbon allowances when he was Secretary of State for the Environment (House of Commons Environmental Audit Committee, 2008; Toynbee, 2006). Unfortunately, Miliband's proposal was then forgotten without even entering a trial phase. Now, since Spain is one of the European countries expected to be more seriously affected by climate change, as well as one of those falling behind regarding green fiscal reform, we now ought to take up the torch, and model and test fair and effective green tax reforms. We now have many methods to avoid regressivity, and surveys show Spanish citizens are ready for and favour a green tax reform (Hanemann, Labandeira, \& Loureiro, 2011). It is politicians that now need to change.

\section{REFERENCES}

Casal, P. (2007). Why sufficiency is not enough. Ethics, 117, 296-326. doi: $10.1086 / 510692$

Cramton, P., \& Stoft, S. (2010). Price is a better climate commitment. The Economists' Voice, 7(1). doi: 10.2202/1553-3832.1718

Fellows, J. A. (1994). Consumption taxes. A view of future tax reform in America. The CPA Journal, 64. Retrieved from http:// links.uv.es/UkECf59

Frank, R., \& Cook, P. J. (1995). The winnertake-all society. New York: Free Press.

Galle, B. (2011). Is cap and trade fair to the poor? George Washington Law Review, 79, 33-110.

Gibbs, T., \& Retallack, S. (2006). TradingUp: Reforming the European Union's emissions trading scheme. London: IPPR.

Goodin, R. (1994). Selling Environmental Indulgencies. Kyklos, 47(4), 573-596.

Hanemann, M., Labandeira, X., \& Loureiro, M. (2011). Climate change, energy, and social preferences on policies. Climate Research, 48(2-3), 343-348. doi: 10.3354/ cr00994

Hansen, J. (2009). Storms of my grandchildren. London: Bloomsbury.

House of Commons Environmental Audit Committee. (2008). Personal carbon trading. Fifth report of session 2007-08. London: The Stationery Office Limited. Retrieved from http:// links.uv.es/Lzqd9XA

McCaffery, E. (1992). Tax policy under a hybrid income-consumption tax. Texas Law Review, 70, 1149-1181.

Pearce, D. (1995). World without end. London: Earthscan.

Piketty, Th. (2014). Capital in the Twenty-First century. Cambridge, MA: The Belknap Press of Harvard University Press.

Poterba, J. M. (1991). Is the gasoline tax regressive? National Bureau of Economic Research. Tax Policy and the Economy, 5, 145-164. doi: $10.3386 /$ w3578

Sandel, M. (2012). What money can't buy. New York: Farrar, Straus and Giroux.

Seidman, L. (1999). The USA tax. Cambridge, MA: MIT Press.

Sterner, T. (2012). Distributional effects of taxing transport fuel. Energy Policy, 41, 75-83. doi: 10.1016/j.enpol.2010.03.012

Tiezzi, S. (2005). The welfare effects and the distributive impact of carbon taxation on Italian households. Energy Policy, 33, 1597-1612. doi: 10.1016/j.enpol.2004.01.016

Toynbee, P. (2006, December 15). This eclectic radicalism marries green politics with social justice. The Guardian, p. 37.

Wier, M., Birr-Pedersen, K., Klinge Jacobsen, H., \& Klok, J. (2005). Are $\mathrm{CO}_{2}$ taxes regressive? Ecological Economics, 52(2), 239-251. doi: 10.1016/ j.ecolecon.2004.08.005

Wilkinson, R., \& Pickett, K. (2009). The spirit level. Why more equal societies almost always do better. London: Penguin.

Paula Casal. ICREA Professor of Moral and Political Philosophy at the Pompeu Fabra University in Barcelona (Spain). She is an associate editor of Politics, Philosophy and Economics, editor of Law, Ethics and Philosophy and president of Academics Stand Against Poverty and of the Great Ape Project-Spain. 